\title{
Research on the Effectiveness of College English Vocabulary Teaching Based on Mobile Learning
}

\author{
Yushuang Zhu \\ College of Foreign Languages, Jianghan University, Wuhan, 430056, China \\ Email: shirley_tony@163.com
}

Keywords: mobile learning; college English; vocabulary teaching; effectiveness

\begin{abstract}
This paper discusses the vocabulary learning mode based on mobile learning by analyzing the characteristics of college students and mobile learning. Mobile learning can break the constraints of time and space in the traditional teaching mode, thus, students can acquire knowledge, communicate and interact with each other and integrate into learning situations at any time and place, fully embodying the student's dominant position in the teaching process. This study verifies the effectiveness of college English vocabulary teaching mode based on mobile learning through empirical research. At the same time, it analyzes the students' attitudes towards mobile learning, the effectiveness of their vocabulary acquisition and the improvement of their autonomous learning ability in vocabulary teaching.
\end{abstract}

\section{Introduction}

Vocabulary occupies a pivotal position in English learning. Wilkins (1972: 111) pointed out that “without grammar, we can only convey very little information. Without vocabulary, we can't communicate anything." [1] During college, students are in advanced stages of English learning. At this time, they have basically mastered English grammar, so vocabulary learning has become an important benchmark for many students to measure their own progress, and it is also an important means to motivate English learning. [2] Therefore, vocabulary teaching has received increasing attention in recent years. [3] Mobile learning breaks the space-time constraints of the traditional teaching mode and enables students to change their passive learning into active learning. Therefore, the vocabulary learning mode based on mobile learning will be the main trend in the future. This paper analyzes the characteristics of contemporary college students and mobile learning, attempting to explore the role of mobile learning in promoting vocabulary learning and the vocabulary learning mode based on mobile learning.

\section{Problems in College English Vocabulary Teaching}

Through years of English learning, college students have accumulated a certain amount of vocabulary and also learned some vocabulary learning methods, such as pronunciation of letters and combinations of letters, affixation, word association, semantic relations, categorization, and other methods to memorize words. Through these traditional vocabulary learning methods, students are able to master the ways of English word formation, which is helpful for the memory of vocabulary, but often because of its boring feature, students gradually lose the enthusiasm for memorizing English vocabulary. [4] At the same time, students in the vocabulary learning also have a sense of dependence on the teacher, which can weaken their initiative gradually; sometimes because of the lack of linguistic context, the vocabulary learning method becomes rigid and single, so that even the students have taken a lot of efforts to memorize the vocabulary, they can't use these words effectively in time due to the low lexical repetition rate. Meanwhile, the form of traditional vocabulary teaching is not flexible enough. [5] It is mainly through grammar indoctrination. Many students are not interested in vocabulary learning. Most of the students are mechanically excerpting notes, thus neither can they keep up with the pace of teaching, nor can they remember vocabulary 
well. Problems such as this are widespread.

\section{Concept and Features of Mobile Learning}

\subsection{Concept of Mobile Learning}

Mobile learning is a new type of learning mode that has emerged with the rapid development and popularization of communication technology in recent years. There is no unified definition yet. In a broad sense, mobile learning refers to the learning that can be happened anytime, anywhere and with any type of device. Hummelet al. (2003) emphasized the contextual relevance of mobile learning. He believed that mobile learning was a ubiquitous link and communication and that a variety of connected devices worked together to create a learning environment so that content could be accessed or communication could be reached anytime and anywhere.

\subsection{Features of Mobile Learning}

Mobile learning has three features. Firstly, mobile learning is autonomous. This mode of learning fully respects the student's dominant position in the learning process, and understands the student's learning needs in time and takes measures to meet the students' various learning needs. Mobile learning pays full attention to the student's personality characteristics, interest and hobbies, and on this basis, fully mobilizes the students' enthusiasm for learning and guides students to consciously complete their learning tasks. Secondly, mobile learning is interactive. Traditional teaching is mostly based on classrooms. This geographical restriction makes it difficult for students at different levels to learn flexibly. Mobile learning, with its unique convenience, has greatly enhanced the interaction between teachers and students and between students. Students can communicate with the classroom in a timely manner through mobile media, and teachers can give students more in-depth and comprehensive guidance. In addition, one-to-one or one-to-many teaching modes can also be formed between teachers and students. Again, mobile learning can break the space-time restrictions. Terminal devices such as smartphones, tablets, and laptops can help students conduct diverse learning activities anytime and anywhere. Teachers can also update the teaching content through the network and adjust the teaching schedule and plan according to the student's message or learning record. It can be seen that mobile learning can help achieve the goal that every student can learn everything at any time and any places.

\section{The Application of Mobile Learning in College Vocabulary Teaching}

The objects of the survey were 80 non-English major students who entered the college in 2015. They were from three classes of the College of Science, Materials, and Electrical Engineering in Jianghan University. According to the student's mobile phone use and their willingness to participate in the experiment, they were divided into experimental group of 30 people and 50 people in the control group. The target vocabulary selected by the study was 100 CET- 6 words that had not been explained in class. The author attempts to use the concept of mobile learning mode into empirical research, and through a four-week experiment quantitatively analyze the learning effect and acceptance of this mode, in order to objectively reflect the advantages of micro-mobility cooperative learning in college English vocabulary learning and provide new ideas and new methods for vocabulary teaching. This study will discuss the following aspects: (1) Whether there is a significant difference in the effectiveness of vocabulary learning from a cooperative and interactive learning mode using mobile tools compared to the traditional paper-based individual learning; (2) Students' attitude towards mobile cooperative vocabulary learning and their recognition of vocabulary learning effectiveness under this mode.

\subsection{Analysis of Vocabulary Pretest and Posttest Results}

The 80 students in the control group and the experimental group conducted the pretest of 100 target vocabularies in early September 2017. After a 4-week experimental study, they conducted the post test of the same test paper on October 8 10. After removing two invalid papers (didn't 
participate in mobile interactive learning as required), 78 valid papers were collected. The author used SPSS data analysis system and Excel data processing to analyze data. Table 1 shows the statistical comparison of performance of the two groups before and after the test.

Table 1 Record results of pretest and posttest

\begin{tabular}{lll}
\hline & Control Group N=50 & Experimental Group N=28 \\
Pretest Mean & $12.3(\mathrm{SD}=2.34)$ & $12.1(\mathrm{SD}=2.40)$ \\
Posttest Mean & $49.4(\mathrm{SD}=4.09)$ & $78.3(\mathrm{SD}=3.72)$ \\
Gain & $37.1(\mathrm{SD}=4.76)$ & $66.2(\mathrm{SD}=4.58)$ \\
$\mathrm{G}(\%)$ & $42.3(\mathrm{SD}=0.049)$ & $75.8(\mathrm{SD}=0.043)$ \\
\hline
\end{tabular}

As can be seen from the values in Table 1, in comparison with the traditional individual learning with paper materials, students in the experimental group achieved significant progress in vocabulary after the adoption of mobile cooperative and interactive learning, and there were significant differences in the detection of learning effects. In the one-sided test of the Gain values before and after the test, $=26.25,=76,<0.01$. Test, $=29.77,=76,<0.01$. The conclusion proves that the difference between the two sample means is extremely significant.

\subsection{Analysis of Questionnaire Results}

The 30 students in the experimental group completed the questionnaires on October 11 12, 2017, and 28 valid papers were recieved. The questionnaire was designed as a closed-ended grading question. The options were: “Agree”, "Not sure” and "Disagree." Representative questions and results are now listed in Table 2, Table 3, and Table 4.

Table 2 Effect of micro-mobility cooperative learning mode on students’ vocabulary learning attitude

\begin{tabular}{|c|c|c|c|c|c|c|}
\hline \multirow{2}{*}{$\begin{array}{l}\text { Item/ } \\
\text { Question } \\
\text { Number }\end{array}$} & \multicolumn{2}{|c|}{ Agree } & \multicolumn{2}{|c|}{ Not sure } & \multicolumn{2}{|c|}{ Don't agree } \\
\hline & $\begin{array}{l}\text { Number of } \\
\text { Students }\end{array}$ & Proportion & $\begin{array}{l}\text { Number of } \\
\text { Students }\end{array}$ & Proportion & $\begin{array}{l}\text { Number of } \\
\text { Students }\end{array}$ & Proportion \\
\hline 1 & 26 & $92.9 \%$ & 2 & $7.1 \%$ & 0 & 0 \\
\hline 2 & 24 & $85.7 \%$ & 3 & $10.7 \%$ & 1 & $3.6 \%$ \\
\hline 3 & 26 & $92.9 \%$ & 2 & $7.1 \%$ & 0 & 0 \\
\hline 4 & 24 & $85.7 \%$ & 2 & $7.1 \%$ & 2 & $7.1 \%$ \\
\hline 5 & 25 & $89.3 \%$ & 2 & $7.1 \%$ & 1 & $3.6 \%$ \\
\hline
\end{tabular}

The data in Table 2 shows that $92.9 \%$ of the students believe that the mobile cooperative learning mode has improved their interest in English vocabulary learning; 85.7\% of students think that the atmosphere is relaxing in mobile cooperative learning; $92.9 \%$ of students consider that mobile cooperative learning makes them learn more actively; $85.7 \%$ of students also said that mobile cooperative learning has improved their confidence in learning vocabulary; 89.3\% of students feel happy and satisfied in this mode of learning. The above data fully demonstrates that mobile cooperative vocabulary learning stimulates students' interest in learning and makes students' learning attitudes become positive.

Table 3 Recognition of vocabulary learning effectiveness in the micro-mobility cooperative learning mode

\begin{tabular}{|c|c|c|c|c|c|c|}
\hline \multirow{2}{*}{$\begin{array}{l}\text { Item/ } \\
\text { Question } \\
\text { Number }\end{array}$} & \multicolumn{2}{|c|}{ Agree } & \multicolumn{2}{|c|}{ Not sure } & \multicolumn{2}{|c|}{ Don’t agree } \\
\hline & $\begin{array}{l}\text { Number of } \\
\text { Students }\end{array}$ & Proportion & $\begin{array}{l}\text { Number of } \\
\text { Students }\end{array}$ & Proportion & $\begin{array}{l}\text { Number of } \\
\text { Students }\end{array}$ & Proportion \\
\hline 6 & 28 & $100 \%$ & 0 & 0 & 0 & 0 \\
\hline 7 & 27 & $96.4 \%$ & 1 & $3.6 \%$ & 0 & 0 \\
\hline 8 & 27 & $96.4 \%$ & 1 & $3.6 \%$ & 0 & 0 \\
\hline 9 & 25 & $89.3 \%$ & 2 & $7.1 \%$ & 1 & $3.6 \%$ \\
\hline
\end{tabular}

Table 3 shows that all students in the experimental group believe that mobile learning helps to 
improve their word memory; $96.4 \%$ of students think that mobile cooperative learning helps to increase their word count, and also believe that they can gain more vocabulary knowledge in the exchanges with team members; $89.3 \%$ of students hold that this learning mode improves their vocabulary use. In short, the vast majority of students in the experimental group highly praised the learning efficiency of the micro-mobile cooperative vocabulary learning mode.

Table 4 Effect of Micro-Mobile Cooperative Learning on Students’ Autonomous and Cooperative Learning Ability

\begin{tabular}{|c|c|c|c|c|c|c|}
\hline \multirow{2}{*}{$\begin{array}{l}\text { Item/ } \\
\text { Question } \\
\text { Number }\end{array}$} & \multicolumn{2}{|c|}{ Agree } & \multicolumn{2}{c|}{ Not sure } & \multicolumn{2}{c|}{ Don't agree } \\
\cline { 2 - 7 } & $\begin{array}{l}\text { Number of } \\
\text { Students }\end{array}$ & Proportion & $\begin{array}{l}\text { Number of } \\
\text { Students }\end{array}$ & Proportion & $\begin{array}{l}\text { Number of } \\
\text { Students }\end{array}$ & Proportion \\
\hline 10 & 26 & $92.9 \%$ & 2 & $7.1 \%$ & 0 & 0 \\
\hline 11 & 27 & $96.4 \%$ & 0 & 0 & 1 & $3.6 \%$ \\
\hline 12 & 23 & $82.1 \%$ & 3 & $10.7 \%$ & 2 & $7.1 \%$ \\
\hline
\end{tabular}

According to the data in Table 4, it can be known that $92.9 \%$ of the students believe that the mobile learning mode helps them to increase self-control in autonomous learning; $96.4 \%$ of the students indicate that they have been given more learning responsibilities in mobile cooperative learning; $82.1 \%$ of the students think that the problems they encounter in learning vocabulary can be solved through mobile interactive communication. It can be seen that mobile learning has a positive influence on students' autonomous and cooperation ability.

The above three sets of data fully prove that mobile vocabulary learning has produced excellent results and positive effects on students' learning attitudes, learning efficiency, and autonomy and cooperation. At the same time, it fully demonstrates that the vast majority of students are willing to take this model.

\section{Conclusions}

Mobile learning not only conforms to the development of the times, but also conforms to the concept of college English teaching reform. It plays a very important role in enriching college English learning vocabulary and promotes the development of mobile learning mode of college English writing. Mobile learning has become more mature, has enriched learning resources and has achieved a variety of learning methods. This article believes that mobile learning breaks the constraints of space and time, enables students to conduct interactive self-study and experience the linguistic context of vocabulary learning. Mobile learning can stimulate the students' subjectivity in English learning and embody the educational concept of "student-centered".

\section{References}

[1] Reviewers for Computer Assisted Language Learning in 2011[J]. Jozef Colpaert. Computer Assisted Language Learning. 2012 (1)

[2] Vocabulary learning by mobile-assisted authentic content creation and social meaning-making: two case studies[J]. L-H. Wong, C-K. Looi. Journal of Computer Assisted Learning. 2010 (5)

[3] Investigating learner preparedness for and usage patterns of mobile learning[J]. Stockwell, Glenn. ReCALL: The Journal of EUROCALL. 2008 (3)

[4] Towards a theory of mobile learning. M. Sharples, J. Taylor, G. Vavoula. Proceedings of Mlearn 2005.

[5] Using mobile phones in English education in Japan[J]. Patricia Thornton, Chris Houser. Journal of Computer Assisted Learning. 2005 (3) 